periodic $\downarrow$ deep inspirations, indicatmg to the sensble individual that he had better seuk a cooler atmosphere. The physiology of this condition appears to be

Ist. That blood is hurried more quickly through the lungs than it ouglit to be, (as will be shown to be the case in speaking of the effect on the circulation.)

2nd. That heat is not a respiratory stimulant

3rd. Respiration is not therefore increased in an equal pro. portion; the normal pulmo cardiac equilibrium is therefore destroyed.

4th. That the rarefied state of the air must influence the oxygenation of the blood unfavourably.

The natural conclusions on this head are therefore-...

1. That the prolonged use of the Turkish bath slowly tends to congestion of the lungs.

2. That too great a heat tends quickly to congestion of the $\operatorname{lun} \curvearrowright s$.

3. That people with a tendency to lung congestion, or hæmoptysis, or weak lung-tissue, ought not without medical permission to indulge in Turkish baths.

Confirmatory observations. - Blagden remarks: "To this circumstance [the increased cardiac action] the oppression on my breath must be partly imputed, the blood being forcer? into my lungs quicker than it could pass through thein; and hence it may very reasonably be conjectured that, should a heat of this kind ever be pnshed so far as to rrove fatal, it will be found to have killed by an accumalation of blood in the lungs, or some other immediate effect of an accelerated circulation."

What is very interesting, however, is that Blagden found the mucus in his lungs after the bath to be more serous than before, "and to incline more to a saltish taste, though the langs themselves seem perfectly sound in all other respects; which raises a suspicion in my mind that some of the sinalle arteries suffered a degree of dilacation from the increased impulse of the blood." + My own experiments also, of drowning animals in hot and cold warer, are to the point, proving that the hot caused greater congestion of the Iungs than the cold.

I have already, in previous papers, shown how the hot bath is highly injurious in the treatment of drowniug. and alluded to the hot air treatment before I had made experiments in the Turkish bath myself; but now, from experience of the effects of the hot air, I can the more strongly affirm all I have previously said. And I think that few who have thonght carefully upon the subject of drowning and its cause, of hot air aud its effects, would employ the latter as a remedy for the evils occasioned by the furmer-an agent that tends to ling cangestion as a remedy for congested lungs; an agent that does not excite respiration for a state where respirition requires to be arousel; an agent of depression for the last stage of apnca and exhaustion.

It would seem that the ancient originators of this kind of bathing had some presentiment of this lung congestion from the heat when they devised bringing the bath to a cold termination. Whether they acted on scientific principles or not, the cold sponuing and imbrification do act as most refreshing physiological excitants to the languid and loaded lungs.

On leaving the hot for the third and cooler room the breathing at once feels easier, but when the coll jets of water play on the surface of the body, the vital processes rejoice; a weight seems taken from the chest, the lungs drink decoly in of the colder air, and new life and vigour seem in consequence to pervade the whole frame.

(To be continued.)

\section{REMOVAL OF A FOREIGN BODY FROM THE VAGINA.}

BY REDFERN DAVIES, ESQ., M.R.C.S., Birmingham.

A woman about forty-five years old, in consequence of being affected with an excessive and troublesome procidentia uteri, had been in the habit of wearing a pessary during the latter part of her life. This pessary was of a globular shape, nine inches in circumference, hollow, made of the usual hard kind of wood, and having at one portion a small part attached, by being screwed into the rest; through two holes a string passed, in order that the pessary might be easily removed when re-

\section{* Phil. Trans, vol. $1 \times 17,1775$, p. 696}

quired to be cleansed. Seven years ago this string broke, and since that time she has been unable to take the pessary away, and has heen troubled with constant hremorrhages, which of liste have become very severe at times, and attended with much pain.

Upon examination I found the pessary to be freely movable, and $I$ thonght that it could be again rithdrawn in the same manner that it had been; and therefore, having steadied the pessary by bolding it with a crotchet, I bored two holes into it, throngh which $I$ conveyed by a bent probe a piece of catgut, and endeavoured to extract it, using as much force as was justifiable, but found I was totally unable to move it downwards more than half an inch, telling the woman that the attempt was a failure, but that should any other means occur to me I would try again.

Upon thiuking the matter over, I reflected that the difficulty in extraction was not due to the prssary itself, it having been frequently introduced and removed before; that, from the material of which it was composed, it was not likely to have undergone any change in shape or structure, although it might have become slightly swollen; that in the vagina there was no swelling or obstruction nor any diminution of calibre from any other cause; that the difficulty experienced in extracting it must be occasioned by the mucous membrane of the vauina becoming rucked up and forming itself into folds when the pessary was being withdrawn, thus rendering an insuperable obstacle to its removal; and that the means to be adopted shnuld be by interposing something between the pessary and the walls of the vagina so as to permit of its being pulled out untouched by them.

To effect this purpose I introduced an ordinary pair of midwifery forceps, so as to embrace the pessary between its blades, and by rhe alreacly inserted string $I$ was enabled easily to draw the pessary downwards, the forceps acting beneficially only by their being interposed between the pessury and the vagina, and not in their ordinary usage-namely, to withdraw the pessary,

The result was in accordance with what was expected, and the pessary, smelling horribly, was easily removed; and under treatment the hamorrhages \&c. entirely ceased.

Birmingham, Ap $\llcorner$ il, 1862.

专

OF THE PRACTIE OF

\section{MEDICINE AND SURGERY IN THE}

\section{HOSPITALS OF LONDON.} Nulla est alia pro certo noscendi via, nisi quam plurimas et morborum $t$ dissectionum historias, tam ation proprias, eollectas habere $\epsilon^{t}$ inter
parare-Nongarr. De Sed. et Caus. Morb., lib. 14. Pronemium.

\section{KING'S COLLEGE HOSPITAL.'}

EXTENSIVE DISEASE OF THE SHOULDER, WITH ABSCESSES AND SINCSES; EXCISION OF THE JOINT; RECOVERY WITH A USEFUL ARM.

\section{(Under-the care of Mr. FrRgussos.)}

Removal of the shoulder joint is comparatively a rare opera. tion, as the cases requiring it are few and infrequently met with. It is resorted to either for disease or injury. Of the latter, $M$. Baudens relates that of fourteen cases occurring in the Crimea amongst the French troops, there was only one death; in the British army, by a siugular coincidence, there were also fourteen cases, of which twelve recovered. The results in ex. cision for disease are not less gratifying; indeed, of all the excisions of joints this is the most successful, notwithstanding the extent and oftentimes apparent gravity of the mischief. The last three cases recorded in our "Mirror" terminated admirably. (The LANCE'T, vol. i., 1860, p. 192.)

We now place on record two additional examples, ending in recovery, with good useful arms; in both the disease was pretty extensive, simulating rheumatism in the commencement.

In the operation the form of incision will vary according to circumstances. Mr. Erichsen thinks the elliptical, or $\mathbf{U}$-shaped, is preferable, as less muscular fibre is sacrificed by it. 'Professor' 